\title{
The relationships between the current administrative policies and the performance of joint service council of solid waste management in the middle and southern areas of Gaza strip
}

\author{
Wasim Al-Habil ${ }^{1}$ \\ ${ }^{1}$ College of Commerce, Islamic University of Gaza, Palestine; Email: Walhabil@iugaza.edu.ps
}

Accepted 19 April, 2016

\begin{abstract}
The research aims to study the relationships between the current administrative policies and the performance of the Joint Service Council of Solid Waste Management in the middle and southern Areas of Gaza Strip. The research used the analytical descriptive methodology and used a questionnaire distributed to a sample consisting of (120) employees who are working in the Joint Service Council of Solid Waste Management in the middle and southern Areas of Gaza Strip (JSC-SWM). Using the Statistical Package for Social Studies program (SPSS), the results indicated that proper budgets, filling positions with local ordinance, pension and retirement system, fines and penalties for violating ordinance, and compensations are not used effectively in the JSCSWM as a tool to promote the performance of the council. The research recommended the activation of scientific tools for designing proper budgets, and unifying the administrative system which regulates the work of the council staff and in the same way of the municipalities' ones.
\end{abstract}

Keywords: budgets, pension, compensations retirement, fines, and penalties

\section{INTRODUCTION}

As the Palestinian National Authority (PNA) started its work in West Bank and Gaza Strip in 1993, it has worked under different rules of management that differs from the liberal-martial management. The role of oversight and administrative control bodies were absent at the beginning which was the most important stage to start control and facing any type of managerial corruption (Coalition for Accountability and Integrity, 2009). Another problem appears in the Palestinian public sector is the effect of the high commitment to the social traditions which implies that people have to help their relatives and friends and they cannot differentiate between helping close people and nepotism. As part of the Palestinian quest to improve the performance of municipal services, and in more specific; to develop the solid waste sector in Palestine, and as part of the National Strategy for Solid Waste Management; new bodies were established to combine the efforts of individual municipalities into what is known as the Joint Service Councils (JSC) (Jabr, 2004). The first JSC concerned with solid waste management in the Palestinian Territory was established in Gaza Strip in 1995 covering the service area of the Middle and Khan Younis Governorates (13 municipalities), followed in 2004 by the formation of second JSC to cover the North Governorate in Gaza Strip - the Solid Waste Management Council in North Gaza Governorate) (Safi and Luecke, 2007). Ever since, several JSCs were established in the West Bank benefiting from the experience in Gaza yet with greater geographic coverage constituting greater number of local government units (municipalities and village councils).

The political and economic factors play crucial role on service provision especially in the aftermath of the Israeli blockade on Gaza and the high unemployment and the subsequent low municipal revenues that contribute to financing the operations of both JSCs where most researchers and reports has focused on. The blockade on Gaza over the last decade has meant that municipal infrastructure was nearing collapse (MDLF, 2009). Nevertheless, effective and sustainable waste 
Table 1: Policy versus Administration

\begin{tabular}{|c|c|}
\hline Policy & Administration \\
\hline Enact a budget & Propose a budget. Spend within budgetary limits. \\
\hline $\begin{array}{l}\text { Define the powers, functions and duties of officers } \\
\text { and employees }\end{array}$ & Fill positions consistent with local ordinances. \\
\hline Fix the compensation of officers and employees. & $\begin{array}{l}\text { Administer payroll consistent with budget and } \\
\text { compensation plan adopted by council. }\end{array}$ \\
\hline $\begin{array}{l}\text { Establish the working conditions of officers and } \\
\text { employees. }\end{array}$ & $\begin{array}{l}\text { Insure that proper working conditions are } \\
\text { provided. }\end{array}$ \\
\hline Establish retirement and pension systems & Administer pension and retirement plan. \\
\hline Adopt ordinances regulating local affairs. & Implement and enforce ordinances. \\
\hline Set fines and penalties for violation of ordinances. & Collect fines and enforce penalties. \\
\hline Enter into contracts. & $\begin{array}{c}\text { Propose contracts. Manage approved contracts. } \\
\text { Enforce contracts. }\end{array}$ \\
\hline $\begin{array}{l}\text { Regulate the acquisition, sale, ownership, and } \\
\text { other disposition of real property. }\end{array}$ & $\begin{array}{l}\text { Negotiate terms of acquisition and sale of real } \\
\text { property; carry out acquisition and sale. }\end{array}$ \\
\hline $\begin{array}{l}\text { Decide which government services will be } \\
\text { provided. Adopt budgets for their provision. }\end{array}$ & $\begin{array}{l}\text { Oversee the day to day operation of programs and } \\
\text { services provided by the local government. }\end{array}$ \\
\hline Establish Public Utilities. & Manage provision of utility services. \\
\hline Grant franchise for the use of public ways. & Enforce terms of franchise agreement. \\
\hline $\begin{array}{l}\text { License, for the purpose of revenue and } \\
\text { regulation, most any type of business. }\end{array}$ & $\begin{array}{l}\text { Administer business licenses as provided by } \\
\text { council. }\end{array}$ \\
\hline $\begin{array}{l}\text { Set tax rates and user fees consistent with state } \\
\text { laws. }\end{array}$ & Collect taxes and user fees. \\
\hline Approve claims against the city of county. & $\begin{array}{l}\text { Bring lawsuits, with legislative approval. Propose } \\
\text { settlement of claims. Pay approved claims. }\end{array}$ \\
\hline Enter into agreements to accept grants and gifts. & $\begin{array}{c}\text { Propose agreements. Carry out terms of } \\
\text { agreement. }\end{array}$ \\
\hline
\end{tabular}

Source: (Municipal Research and Services Center of Washington, 1999, p. 18)

management goes hand-in-hand with good public service and sound municipal management.

\section{Research problem}

The research studies the relationship between the current administrative policies and the performance of joint service council of solid waste management (JSC-SWM) in the middle and southern areas of Gaza Strip. Solid waste management strategies cannot be executed without the support and guidance of proper administrative framework. Administration should contain a series of ordinances and regulations aimed at managing solid waste, including procedures and methodologies for monitoring and enforcing the regulations. Consistent national policies on MSW administration are needed. The policies should encourage cross-jurisdictions and interagency coordination, and facilitate implementation of economic instruments for improving the performance of the solid waste management councils, (Li, 2007, p. 11). According to Municipal Research and Services Center of Washington (1999), public bodies including the joint service councils of the solid waste management should adopt proper budgets, fill all positions with local ordinances, administer payroll consistently, pension and retirement plans, and collect fines and enforce penalties and other factors listed in the table 1.

The research question: What is the relationship between the current administrative policies and the performance of joint service council of solid waste management in the middle and southern areas of Gaza Strip?

\section{Research Variables}

\section{Dependent Variable: Performance of JSC-SWM}

Independent Variables: Administrative policies, Adopting proper budgets, Filling positions with local ordinances, Pensions and retirement system, Fines and penalties for violation of ordinances, Compensations, Personal characteristics among employees (sex, age, and education). 


\section{Hypothesis}

The research studied the following hypothesis:

\section{The Major Hypothesis:}

- There is a statistically significant relationship at $\mathbf{a}=0.05$ between the current policies and the performance of the JSC-SWM.

This hypothesis is subdivided into the following hypotheses:

- There is a statistically significant relationship at $\mathbf{a}=0.05$ between adopting proper budgets and the performance of the JSC-SWM.

- There is a statistically significant relationship at $\mathbf{a}=0.05$ between filling positions with local ordinance and the performance of the JSC-SWM.

- There is a statistically significant relationship at $\mathbf{a}=0.05$ between pension and retirement system and the performance of the JSC-SWM.

- There is a statistically significant relationship at $\mathbf{a}=0.05$ between fines and penalties for violation of ordinance and the performance of the JSCSWM.

- There is a statistically significant relationship at $a=0.05$ between compensations and the performance of the JSC-SWM.

- There is a statistically significant relationship at $\mathbf{a}=0.05$ in the responses due to the differences of personal characteristics among employees (experience, education, and profession).

\section{Research objectives}

The research aims to achieve multiple objectives identified as follow:

- To identify the current administrative policies implemented by JSC-SWM in the middle and southern areas of Gaza Strip.

- To identify the extent to which these administrative policies are effective at performance of employees.

- To draw conclusions and recommendations about how to modify and reactivate these administrative policies.

\section{Importance of the research}

The importance of the research comes from the rareness of the studies about the administrative mechanisms, techniques, and tools used by the Palestinian public sector generally and JSC-SWM particularly to promote the public services to citizens. The research was conducted during a critical period of time as there are many calls for the reconditioning and reforming all the systems of the Palestinian National Authority (PNA). On the other hand, the research could be used as a base to conduct an advanced future research of how to improve administrative policies to make them more effective and more suitable to the Palestinian context and public servants in JSC-SWM.

\section{Palestinian context of Solid Waste Management:}

Human activities produce volumes of unwanted materials known as solid wastes called "garbage" or "trash". Such unwanted material poses public health threat and unpleasant smells in addition to the damage to the aesthetics setting of a city, village, or the landscape of a country. Solid Waste also has other impacts on the entire environment with its air, ground water, and soil. In most countries, the local government or municipality or local government unit is responsible for managing solid waste, (Diaz et al., 2005). Solid waste management (SWM) "encompasses the functions of collection, transfer, treatment, recycling, resource recovery and disposal of municipal solid waste. Its first goal is to protect the health of the population, particularly that of low- income groups. Other goals include promotion of environmental quality and sustainability, support of economic productivity and employment generation. Achievement of SWM goals requires sustainable SWM systems, which are adapted to and carried by the municipality and its local communities." (Bushra, 2000, p. 8)

In this research, the focus is made on municipal solid waste being the largest in volume in developing countries including Palestine. For simplicity, municipal solid waste (MSW) is produced primarily by ordinary activities in connection to households and similar activities like commercial activities and other public activities, (EEA, 2013). The collection of solid waste is typically labor intensive where municipalities rely on labor to collect trash bags or empty waste bins into collection vehicles that range in type and size. SWM process does not end at the collection of "trash", rather it continues into transferring such unwanted material to its final destination; the landfill, where it is buried and covered with earth material or as approved depending on the regulator's requirements. In Gaza, the solid waste does not undergo resource recovery process where recyclable materials, such as plastics, metals, paper, and glass are filtered out to go back to factories that use them as input into new products.

In the last 20 years, the European Union (EU) has presented a large body of waste legislation, including minimum requirements for managing certain waste types. "Three targets in particular should have led to a convergence of municipal waste recycling levels across Europe: the Landfill Directive's landfill diversion target for biodegradable municipal waste; the Packaging and 
Table 2: Estimated Solid Waste Management Costs between 2010 and 2025

\begin{tabular}{lcc}
\hline Country Income Group & 2010 Cost & 2025 Cost \\
\hline Low Income Countries & $\$ 1.5$ Billion & $\$ 7.7$ Billion \\
Lower Middle Income Countries & $\$ 20.1$ Billion & $\$ 84.1$ Billion \\
Upper Middle Income Countries & $\$ 24.5$ Billion & $\$ 63.5$ Billion \\
High Income Countries & $\$ 159.3$ Billion & $\$ 220.2$ Billion \\
Total Global Cost (US\$) & $\$ 205.4$ Billion & $\$ 375$ Billion \\
\hline
\end{tabular}

Source: (Hoornweg and Bhada-Tata, 2012, p. 46)

Packaging Waste Directive's recycling targets; and the Waste Framework Directive's recycling target for household and similar wastes", (EEA, 2013). In Palestine as a case of developing countries, the issue of solid waste may not gain a priority status on national agendas, thus the entire process of solid waste management would seem far underdeveloped when compared to industrialized nations in Europe and North America. "In an attempt to accelerate the pace of its industrial development, an economically developing nation may fail to pay adequate attention to solid waste management. Such a failure incurs a severe penalty at a later time in the form of resources needlessly lost and a staggering adverse impact on the environment and on public health and safety", (Diaz et al., 2005).

\section{Financial aspects}

In terms of financing, low income countries generate less solid waste and spend less cost while the high income countries generate more solid waste and spend more cost. Table 2 shows the estimated solid waste management cost between 2010 and 2025.

Palestinian Local Government Law of 1997 created the legal basis for establishing an institutional framework, such as a solid waste management council, that can manage a regional landfill facility and municipal waste collection on a district and regional scale. Article No. 15, Paragraph 8, stated that all local authorities are responsible for collecting SW from public places, transporting and disposing these wastes in designated areas. The same article stipulates that all local authorities shall take all precautions and procedures necessary to maintain public health and prevent outbreaks of epidemics among the people (Soufan, 2012).

On the operational level, the World Bank (2012) estimated that the collection rate of the solid waste in the West Bank and Gaza is $85 \%$ in urban areas. The collection rate of solid waste puts Palestine in the ranks of middle and high income countries. the central government showed no spending at all while external donors provided 5.4 million US dollars and 11.6 million US dollars in 2011 and 2012 respectively (PCBS, 2012).

The Palestinian Central Bureau of Statistics (PCBS) indicated in 2012 that the Palestinian government did not finance any infrastructure investment in the SWM sector in the West and Gaza, while foreign donors reserved almost $29 \%$ of their financing in the environment sector for SWM. The below figure illustrates that, and it can be concluded that investment in the solid waste management sector is entirely left for external donations. However, the same data showed the Palestinian government spending $27 \%$ of its finance in the environment sector in 2012, or 7,100,000 US dollars, for management, regulation, capacity building, and salaries which indicate the Palestinian government's commitment to support operational aspects of SWM, i.e, salaries and running costs. It should be noted the local authorities collect fees for SWM services, but the collected fees are not enough to cover operational costs due to the economic conditions in Gaza and citizen's inability to pay (MDLF, 2014). Figure 1 shows Palestinian governmental expenditure on environment in 2012.

\section{Institutional aspects}

Two government bodies are primarily responsible for SWM in Palestine; the Ministry of Local Government (MoLG), and the Environment Quality Authority (EQA). MoLG is the main coordinating agency for solid waste management within the Occupied Palestinian Territories, having overall responsibility for the relevant functions of local authorities and it supervises the establishment of the regional solid waste management. On the other hand, EQA is responsible for licensing of sites, environmental monitoring, provision of expertise and ensuring environmental protection. Other governmental agencies have roles but at different degrees concerning specific themes within the SWM sector. For instance, the Ministry of Health is concerned with the health care medical waste 

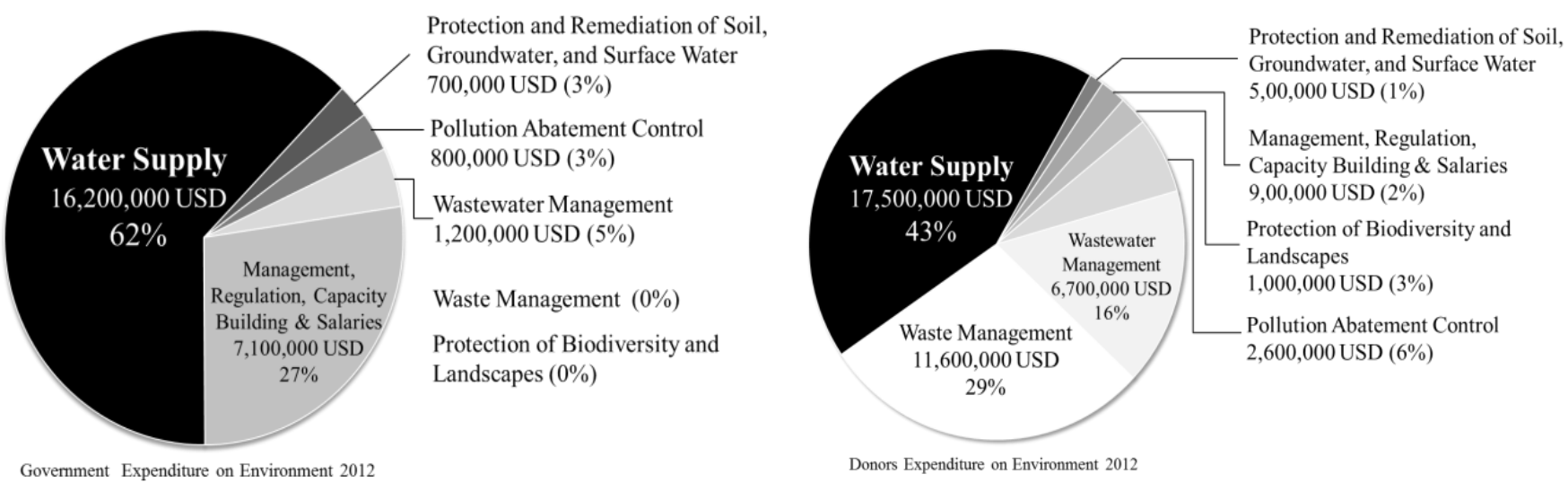

Figure 1: Governmental Expenditure on Environment in Palestine 2012; left: Palestinian government's expenditure, right: donors' expenditure. Data source: (PCBS, 2012)

that consists of hazardous waste. The Ministry of Planning and International Cooperation is responsible for the overall planning and fund raising (El-Medhoun, 2015).

Most of the day-to-day processing of solid waste (collection, transportation and disposal of waste, and operation and maintenance of facilities) is the responsibility of the local authorities. In larger towns and cities, this is usually the local municipality, while in smaller localities the village councils play a key role, often with coordination provided by the district authorities (UNEP, 2003).

\section{The Joint Service Councils (JSC)}

In 2004, MoLG established the General Directorate of Joint Services Councils for Planning and Development(GDJSC) within the ministry with a main purpose of setting forth the policies with regard to forming and supervising the Joint Service Councils for Planning and Development in the West Bank and Gaza (MoLG, 2009). The objectives of the GDJSC are to:

- Enhance the joint councils and prepare them for amalgamation, thus contributing to sustainable cooperation between local units.

- Reinforce cooperation and integration among the joint councils within the framework of the Palestinian local government system.

- Reinforce the capacities of the General Directorate of Joint Councils and enhance their role as a technical arm for the Ministry in the sector.

- Support the joint councils to ensure their sustainability and enhance their capacities to help them perform their duties (El-Medhoun, 2015).

In 2006, the MoLG adopted the Statute of Joint Service Councils. The Statute defines rules of establishing JSCs, and elaborates their jurisdiction, membership, administrative structure, reporting, election and voting mechanisms. It also defines the "General Assembly" and "Board of Directors" of the JSC and sets out the roles and responsibilities of each. The key staff that must be retained by the JSC are also established in the Statute. The legal and financial status of a JSC established under the Statute derives from the legal status of its Local Government Unit (LGU) members. The MoLG has oversight responsibility for JSC's (Daifi, 2012, p. 67).

Table 2 provides the number and type of JSCs in the West Bank and Gaza. The multilateral JSC provides various services for a group of LGU's, while the single JSC is concerned with one type of service for LGU's, e.g., solid waste management or water. (MoLG, 2009). Table 3 shows the types of joint service councils in Palestine.

\section{LITERATURE REVIEW}

Bel and Warner, (2013) looked into the motivations for inter-municipal cooperation, where the researchers used fiscal constraints, economies of scale, community wealth, organizational factors (manager), and special factors as dependent variables and concluded that the theoretical expectations that fiscal constraints are significant factors for cooperation for small municipalities, but the case vary when larger samples were studied to find that "Technological improvements in service quality and the need to coordinate services across the metropolitan region are increasingly being referenced in the qualitative literature on cooperation as important drivers." Thus the researcher suggested that other factors could be important in explaining cooperation. The importance of this paper that it pointed to the direction of other factors other than economic savings benefits of joint service provision; something that can benefit our research in 
Table 3: Type of Joint Service Councils for Planning and Development (April 2008)

\begin{tabular}{|c|c|c|c|c|c|c|}
\hline \multirow{2}{*}{ Governorate } & \multirow{2}{*}{ Municipality } & \multirow{2}{*}{ Village } & \multirow{2}{*}{$\begin{array}{c}\text { Local } \\
\text { Community }\end{array}$} & \multirow{2}{*}{ Total } & \multicolumn{2}{|c|}{ JSC } \\
\hline & & & & & Single & Multilateral \\
\hline 1. Jenin & 12 & 30 & 34 & 76 & 11 & 4 \\
\hline 2. Tubas & 3 & 5 & 7 & 15 & 1 & 2 \\
\hline 3. Nablus & 9 & 49 & 1 & 59 & 1 & 5 \\
\hline 4. Tulkerm & 11 & 17 & 5 & 33 & 2 & 4 \\
\hline 5. Qalkilia & 5 & 12 & 17 & 34 & 1 & 3 \\
\hline 6. Salfeet & 9 & 10 & - & 19 & 1 & 3 \\
\hline 7. Ramallah & 18 & 48 & 2 & 68 & 13 & 2 \\
\hline 8. Jerusalem & 10 & 17 & 1 & 28 & 1 & 5 \\
\hline 9. Jericho & 3 & 5 & - & 8 & 1 & 3 \\
\hline 10. Bethlehem & 10 & 20 & 8 & 38 & 5 & 3 \\
\hline 11. Hebron & 17 & 22 & 40 & 79 & 2 & 4 \\
\hline 12. Gaza & 25 & - & - & 25 & 6 & 3 \\
\hline Total & 132 & 235 & 115 & 482 & 45 & 41 \\
\hline
\end{tabular}

Source: Ministry of Local Government (MoLG, 2009)

Gaza in modifying the conventional understanding of regional approaches (JSC) for sustainable service provision,.

Al-Masri, (2012) aimed in his research at identifying the impact of role ambiguity on delegation of tasks and authority at the Ministry of Local Government (MoLG). He concluded that although the staff of MoLG are aware of the Ministry's mission but less awareness was expressed by the respondents on more strategic issues and even on the detailed job description and specific roles of staff members.

Bolgherini, (2011) explored the relationships pertaining to government and governance at local level presenting two case studies from Italy and Germany. The researcher explained the purpose of this paper as an attempt "to show that the success of local territorial policies and reforms, such as the IMC (Inter-Municipal Cooperation) experiences, greatly depend on an efficacious balance between deliberative bodies, participatory modalities and "free choices" of the local actors, on the one side, and representative institutions, hierarchical decisions and centralistic guidelines, on the other side" (Bolgherini, 2011 , p. 5). The researcher concluded that direct comparison of two adjacent and pioneer countries in the area of municipal services and local governance is very important to learn from. This study can add to the value of this research in Gaza in terms of better exploration of the interrelations among municipalities and the central government.

Abu Al-Aajeen, 2010 aimed in his research at identifying the impact of organizational obstacles on the performance of local authorities in Gaza Strip where he distributed a questionnaire to the local authorities (municipalities) in Gaza Strip. The researcher came with several recommendations, one of which is related to the human resource development (training and development) and the incentive system in Gaza municipalities, which the respondents indicated that both areas needed development and support by the local authorities.

Saleh and Saad, (2010) did a study on four major Iraqi Governorates examining the level of services and correlated its ineffectiveness to the lack of administrative practices. The researchers recommended the establishment of Joint Service Councils citing number of its benefits and considering that approach as of "a modern local governance approach" (Saleh and Saad, 2010, p. 183). The importance of this study that presents an example that is well behind the experience in Palestine.

Shorab's 2007 study aimed to identify the strength and weaknesses in the incentive system in the large municipalities of Gaza Strip and to explain the relationship between incentives and performance. The study used the analytical descriptive methodology with SPSS and used a questionnaire for the sample consisting of 55 employees who are working in supervision jobs. The study found that the employees are not satisfied with the incentives' system, but they respond well to unfinancial incentives, although that their performance wasn't up to the needed performance to achieve goals. It recommends municipalities should pay more attention to the financial reinforcements and connect it with the results of performance appraisal only.

Al-Aksh, (2007) aimed to evaluate the effectiveness of the reinforcement system in the Palestinian public sector; it also aimed to evaluate the role of these reinforcements on the performance of public employees. The study used the analytical descriptive methodology, SPSS and used a questionnaire for the sample which consisted of 346 employees who are working in managerial and supervisor positions in the Palestinian ministries. The study found that the effect of incentives and rewards system on 
Table 4: Correlation coefficient of each field in the questionnaire.

\begin{tabular}{lcc}
\hline Field & Pearson Correlation Coefficient & P-Value (Sig.) \\
\hline Adopting proper budgets & 0.656 & $0.000^{*}$ \\
Filling Positions with local ordinance & 0.814 & $0.000^{*}$ \\
Pensions and retirement system & 0.643 & $0.000^{\star}$ \\
Compensations & 0.607 & $0.000^{\star}$ \\
Fines and penalties for violation of ordinances & 0.311 & $0.045^{*}$ \\
\hline
\end{tabular}

${ }^{*}$ Correlation is significant at the 0.05 level.

improving the performance of the employees in PNA ministries is very weak, inactive and most of the employees don't have any idea about the system. The study recommends that the incentives system should be checked and reevaluated, updated to fit the expectations of the employees in the public sector, and increased for the competent and active employees.

Awad, (2005), aimed to evaluate the performance appraisal system which is being used in the PNA and how it affects the employee's performance. The study used the analytical descriptive methodology with SPSS and used a questionnaire for the sample consisting of 520 employees from the middle managers who are working in PNA institutions in Gaza strip. The study found that there is no relationship between employee's performance appraisal and the reinforcements which he/she is going to receive and most of supervisors don't know how to deal with unacceptable behaviors or how to implement punishment policies when it's needed. It recommends that human resources departments have to give more attention to the performance appraisal process and top management should be committed to this process to make it effective, valid, and trusted.

Kolab, (2004) aimed to evaluate the application of the internal monitoring system in the Palestinian public sector and to examine the relationship between the internal monitoring system and corruption and poor performance. The study used the analytical descriptive methodology with SPSS and used a questionnaire for the sample which consisted of 130 employees in 22 ministries. The study found that the weaknesses in the internal monitoring system are considered the most important reason for the administrative and financial corruption. It recommends that government should improve the coordination between the internal monitoring units in the different ministries, improve the used criteria of performance appraisal to make them able to measure the real level of performance, and activate the accounting system by legislating the needed laws which can define the procedures of how to deal with corruptors.

Abo-Made, (2004) aimed to evaluate the effectiveness of the control methods in the Palestinian public sector and how these tools are being used to improve the performance of public employees. The study used the analytical descriptive methodology with SPSS and used two questionnaires for two different samples. The first one consisted of 380 mangers from the public sector institutions, and the other one consisted of 500 citizens in the Gaza Strip. The study found the Palestinian public institutions use budgets as a control tool, but this use is not effective so it affects the level of performance negatively. In addition, most of public sector's mangers don't use planning in performing their tasks, or in measuring performance. The study recommends government should start staffing according to the needed qualifications instead of the political belongingness.

\section{METHODOLOGY}

The population of the research consists of all the employees in JSC-SWM in the middle and southern areas of the Gaza Strip. The data collection depended on the survey method which included all the 120 employees in the JSC-SWM. The Data analysis was performed by using (SPSS 22) application. Various statistical methods were utilized including Kolmogorov-Smirnov test of normality, Cronbach's Alpha for Reliability Statistics, Pearson correlation for Validity, and others.

Statistical Validity of the Questionnaire: To insure the validity of the questionnaire, two statistical tests of the validity and credibility were applied:

Structure's Validity: The researcher assessed the fields' structure validity by calculating the correlation coefficients of each field of the questionnaire. Table 4 shows the Correlation coefficient of each field in the questionnaire. Table 4 clarifies the correlation coefficient for each filed and the whole questionnaire. The p-values (Sig.) are less than 0.05 , so the correlation coefficients of all the fields are significant at $\alpha=0.05$, so it can be said that the fields are valid to measure what it was set for to achieve the main aim of the research.

Reliability: Table 5 shows the values of Cronbach's Alpha for each filed of the questionnaire and the entire questionnaire. For the fields, the values of Cronbach's Alpha are in the range from 0.62 and 0.73 . This range is considered high; the result ensures the reliability of each field of the questionnaire. Cronbach's Alpha equals 0.72 for the entire questionnaire which indicates an excellent reliability of the entire questionnaire. Thereby, the questionnaire was valid and reliable. 
Table 5: Cronbach's Alpha for each filed of the questionnaire and the entire questionnaire

\begin{tabular}{llcc}
\hline No. & Field & Cronbach's Alpha & Consistency $^{*}$ \\
\hline 1 & Adopting proper budgets & 0.62 & 0.78 \\
2 & Filling Positions with local ordinance & 0.66 & 0.81 \\
3 & Pensions and retirement system & 0.64 & 0.80 \\
4 & Compensations & 0.73 & 0.85 \\
5 & Fines and penalties for violation of ordinances & 0.67 & 0.82 \\
\hline Total & & $\mathbf{0 . 7 2}$ & $\mathbf{0 . 8 5}$ \\
\hline
\end{tabular}

Table 6: Kolmogorov-Smirnov Test of Normality.

\begin{tabular}{lcc}
\hline \multirow{2}{*}{ Variables } & \multicolumn{2}{c}{ Kolmogorov-Smirnov } \\
\cline { 2 - 3 } & Test Value & P-value \\
\hline Adopting proper budgets & 0.681 & 0.743 \\
Filling Positions with local ordinance & 0.974 & 0.299 \\
Pensions and retirement system & 0.699 & 0.713 \\
Compensations & 0.962 & 0.287 \\
Fines and penalties for violation of ordinances & 0.763 & 0.358 \\
ALL independent variables together & 0.692 & 0.724 \\
\hline
\end{tabular}

Test of Normality: The One-Sample KolmogorovSmirnov Test procedure compares the observed cumulative distribution function for a variable with a specified theoretical distribution, which may be normal, uniform, Poisson, or exponential. The KolmogorovSmirnov $Z$ is computed from the largest difference (in absolute value) between the observed and theoretical cumulative distribution functions. This goodness-of-fit test tests whether the observations could reasonably have come from the specified distribution. Many parametric tests require normally distributed variables. The onesample Kolmogorov-Smirnov test can be used to test that a variable of interest is normally distributed.

Table 6 shows the results for Kolmogorov-Smirnov test of normality. From Table 3.6, the p-value for each variable is greater than 0.05 , and then the distributions for these variables are normally distributed. Consequently, parametric tests will be used to perform the statistical data analysis.

\section{Data analysis}

\section{Personal characteristics}

Personal characteristics contain sex, age, profession, qualifications in the JSC-SWM in the middle and southern areas of Gaza Strip. Table 7 shows personal characteristics of the sample.

\section{Hypotheses testing}

Hypothesis 1: There is a statistically significant relationship at $\mathbf{a}=0.05$ between adopting proper budgets and the performance of the JSC-SWM. Table 8 shows the means and test values for the first field. According to Table 8, the mean of the paragraph \#8 equals 3.79 $(75.74 \%)$, test-value $=11.06$, and P-value $=0.000$, which is smaller than the level of significance. The sign of the test is positive, so the mean of this paragraph is significantly greater than the hypothesized value 3 . It can be conclude that the respondents agreed to this paragraph.

According to the data in table 8 , it can be concluded that there is a significant relationship between adopting proper budgets and the performance at level of (0.05), which means that financial reinforcements have a very important effect on employees' performance.

Hypothesis 2: There is a statistically significant relationship at $\mathbf{a}=0.05$ between filling positions with local ordinance and the performance of the JSC-SWM. Table 9 shows means and test values for the second field. Table 9 shows that the mean of the paragraph\#16 equals 3.54 $(70.81 \%)$, test-value $=8.40$, and P-value $=0.000$, which is smaller than the level of significance. The sign of the test is positive, so the mean of this paragraph is significantly greater than the hypothesized value 3 . It can 
Table 7: Personal characteristics of the sample

\begin{tabular}{llcc}
\hline Personal characteristics & Frequency & Percent \\
\hline \multirow{4}{*}{ Gender } & Male & 30 & 25 \\
& Female & 90 & 75 \\
& Total & 120 & 100.0 \\
Age & $20-30$ & 50 & 41.6 \\
& $31-40$ & 33 & 27.6 \\
& $41-50$ & 17 & 14.2 \\
& $51-60$ & 20 & 16.6 \\
\multirow{4}{*}{ Qualifications } & Total & 120 & 100.0 \\
& Ph.D. & 1 & .83 \\
& Master & 7 & 5.83 \\
& Bachelor & 45 & 37.5 \\
& Diploma & 44.16 \\
& Others & 53 & 11.6 \\
& Total & 14 & 100.0 \\
& Director & 120 & 0.83 \\
& Head of Department & 1 & 4.16 \\
& Head of Division & 5 & 2.5 \\
& Engineer & 3 & 6.66 \\
& Administrative & 8 & 10 \\
& Technician & 12 & 17.5 \\
& Laborer & 21 & 34.16 \\
& drivers & 41 & 10 \\
& Other & 12 & 14.16 \\
& Total & 17 & 100.0 \\
\hline
\end{tabular}

Table 8: Means and Test values for the first field.

\begin{tabular}{|c|c|c|c|c|c|c|}
\hline No & Item & 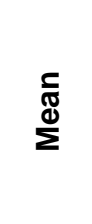 & 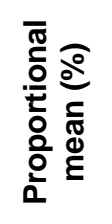 & 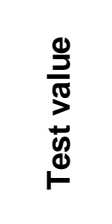 & $\begin{array}{l}\widehat{D} \\
\frac{0}{0} \\
\frac{0}{J} \\
\frac{D}{\pi} \\
\frac{1}{1}\end{array}$ & 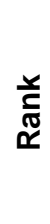 \\
\hline 1 & Employees participate in designing the annual budget. & 2.54 & 50.72 & 5.92 & $0.000^{*}$ & 3 \\
\hline 2 & $\begin{array}{l}\text { The administration designates financial reinforcements in } \\
\text { the budget. }\end{array}$ & 1.92 & 38.37 & 13.63 & $0.000^{*}$ & 8 \\
\hline 3 & $\begin{array}{l}\text { The financial reinforcements provided to employees are } \\
\text { sufficient to do the job well. }\end{array}$ & 2.36 & 47.23 & 8.90 & $0.000^{*}$ & 4 \\
\hline 4 & $\begin{array}{l}\text { The administration of JSC allows employees to review } \\
\text { the budget. }\end{array}$ & 2.14 & 42.76 & 11.73 & $0.000^{*}$ & 6 \\
\hline 5 & Administration publishes its annual budget to public & 1.94 & 38.83 & 12.98 & $0.000^{*}$ & 7 \\
\hline 6 & $\begin{array}{l}\text { Administration depends on financial experts to design the } \\
\text { annual budget. }\end{array}$ & 2.18 & 43.53 & 11.31 & $0.000^{*}$ & 5 \\
\hline 7 & $\begin{array}{l}\text { Administration adopts audit policy for its expenditures } \\
\text { and revenues. }\end{array}$ & 3.16 & 63.13 & 1.63 & $0.051^{*}$ & 2 \\
\hline 8 & $\begin{array}{l}\text { Administration shares employees in budgetary problems, } \\
\text { solutions, and financial suggestions }\end{array}$ & 3.79 & 75.74 & 11.06 & $0.000^{*}$ & 1 \\
\hline
\end{tabular}

*The mean is significantly different from 3 
Table 9: Means and Test values for the second field.

\begin{tabular}{|c|c|c|c|c|c|c|}
\hline No & Item & $\begin{array}{l}\text { c } \\
\stackrel{\mathbb{\varpi}}{\Sigma} \\
\Sigma\end{array}$ & 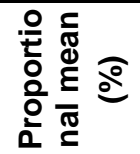 & 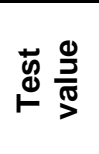 & $\frac{0}{\frac{2}{\sigma}} \widehat{D}$ & \\
\hline 9 & The administration fills all the vacancies in the council. & 2.65 & 52.96 & 4.20 & $0.000^{*}$ & 7 \\
\hline 10 & $\begin{array}{l}\text { The administration publishes all the vacancies for one } \\
\text { month before the process of screening }\end{array}$ & 2.73 & 54.65 & 3.59 & $0.000^{*}$ & 5 \\
\hline 11 & $\begin{array}{l}\text { The publicity of vacancies matches with the legal policies } \\
\text { and procedures of the Palestinian labor law. }\end{array}$ & 2.66 & 53.21 & 5.21 & $0.000^{*}$ & 6 \\
\hline 12 & $\begin{array}{l}\text { All applications are screened based on equity and } \\
\text { transparency. }\end{array}$ & 2.85 & 56.99 & 1.45 & 0.074 & 4 \\
\hline 13 & All candidates require passing a relevant written test. & 2.88 & 57.54 & 0.30 & 0.381 & 3 \\
\hline 14 & All candidates require passing a competitive interview. & 2.63 & 52.67 & 5.52 & $0.000^{*}$ & 8 \\
\hline 15 & $\begin{array}{l}\text { All successful candidates are contracted according to the } \\
\text { terms and rules of the Palestinian Civil Service Law. }\end{array}$ & 3.19 & 63.82 & 2.72 & $0.003^{*}$ & 2 \\
\hline 16 & $\begin{array}{l}\text { All successful candidates receive a written copy of their } \\
\text { job description before starting their work. }\end{array}$ & 3.54 & 70.81 & 8.40 & $0.000^{*}$ & 1 \\
\hline
\end{tabular}

* The mean is significantly different from 3

Table 10: Means and Test values for the third field

\begin{tabular}{|c|c|c|c|c|c|c|}
\hline No & Item & $\stackrel{\frac{5}{\Phi}}{\Sigma}$ & 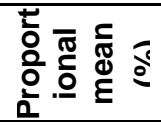 & 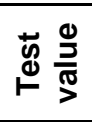 & 旁 $\widehat{D}$ & 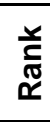 \\
\hline 17 & $\begin{array}{l}\text { All employees are subjected to a unified law in terms of } \\
\text { pension and retirement. }\end{array}$ & 2.94 & 58.88 & 0.18 & 0.429 & 4 \\
\hline 18 & $\begin{array}{l}\text { Employees believe that their future plans of pension } \\
\text { and retirement are less than their expectations. }\end{array}$ & 3.10 & 61.95 & 1.78 & $0.037^{*}$ & 3 \\
\hline 19 & $\begin{array}{l}\text { Employees feel secure under the current policies of } \\
\text { pension and retirement. }\end{array}$ & 3.39 & 67.78 & 5.56 & $0.000^{*}$ & 2 \\
\hline 20 & $\begin{array}{l}\text { The administration of the council reviews the policies of } \\
\text { pension and retirement with its staff. }\end{array}$ & 3.48 & 69.55 & 6.73 & $0.000^{*}$ & 1 \\
\hline 21 & $\begin{array}{l}\text { The employees believe that their future plans of } \\
\text { pension and retirement are essentials for their career } \\
\text { development. }\end{array}$ & 2.78 & 55.59 & 4.32 & $0.000^{*}$ & 5 \\
\hline 22 & $\begin{array}{l}\text { Employees think of resigning if they find another better } \\
\text { employment opportunity. }\end{array}$ & 2.63 & 52.58 & 6.13 & $0.000^{*}$ & 6 \\
\hline
\end{tabular}

*The mean is significantly different from 3

be concluded that the respondents agreed to this paragraph.

According to the data in table 9, it can be concluded that there is a significant relationship between filling positions with local ordinance and the performance of the JSC-SWM at level of (0.05), which means that also filling positions with local ordinance have important effect on performance of JSC-SWM.

Hypothesis 3: There is a statistically significant relationship at $\mathbf{a}=0.05$ between pension and retirement system and the performance of the JSC-SWM. Table 10 shows the means and test values for the third field.

According to the data in table 10, it can be concluded that there is a significant relationship between pension and retirement system and the performance of the JSCSWM at level of (0.05).

Hypothesis 4: There is a statistically significant relationship at $\mathbf{a}=0.05$ between fines and penalties for violation of ordinance and the performance of the JSCSWM. Table 11 shows that means and test values for the fourth field.

According to the data in table 11, it can be concluded that there is a significant relationship between fines and penalties for violation of ordinance and the performance of the JSC-SWM at level of (0.05).

Hypothesis 5: There is a statistically significant relationship at $\mathbf{a}=0.05$ between compensations and the 
Table 11: Means and Test values for the fourth field

\begin{tabular}{|c|c|c|c|c|c|c|}
\hline No. & Item & 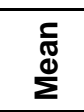 & 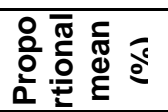 & 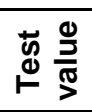 & 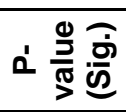 & 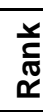 \\
\hline 24 & $\begin{array}{l}\text { The council adopts a written-policy of the financial } \\
\text { punishments provided by law to the new employee and } \\
\text { partners. }\end{array}$ & 2.86 & 57.19 & 1.25 & 0.106 & 4 \\
\hline 25 & $\begin{array}{l}\text { There is a lack of regulating the bylaws related to fines } \\
\text { and penalties against the uncommitted partners. }\end{array}$ & 3.32 & 66.43 & 6.32 & $0.000^{*}$ & 1 \\
\hline 26 & $\begin{array}{l}\text { The council punishes its partners for not paying its } \\
\text { financial commitments to the council. }\end{array}$ & 2.96 & 59.16 & 0.31 & 0.378 & 3 \\
\hline 27 & $\begin{array}{l}\text { There is a clear written policy of fines and penalties for } \\
\text { violation of ordinance against the partners in case of } \\
\text { violation. }\end{array}$ & 2.98 & 59.64 & 0.06 & 0.475 & 2 \\
\hline 28 & $\begin{array}{l}\text { The council should design a clear cut policy explaining } \\
\text { the adopted fines and penalties for violation of ordinance. }\end{array}$ & 2.78 & 55.60 & 3.79 & $0.000^{*}$ & 5 \\
\hline 29 & $\begin{array}{l}\text { The council should reconsider the membership of the } \\
\text { partners who delay the payments of their debts. }\end{array}$ & 2.49 & 49.79 & 6.59 & $0.000^{*}$ & 7 \\
\hline 30 & $\begin{array}{l}\text { The council should design its relationship with partners } \\
\text { based on their financial commitment toward the council. }\end{array}$ & 2.54 & 50.90 & 6.31 & $0.000^{*}$ & 6 \\
\hline
\end{tabular}

*The mean is significantly different from 3

Table 12: Means and Test values for the fifth field

\begin{tabular}{lllllll}
\hline No Item & & & & & & \\
\hline 31 & $\begin{array}{l}\text { The salary scale of the council has no unified legal } \\
\text { basis. }\end{array}$ & 2.39 & 47.87 & 9.61 & $0.000^{*}$ & 4 \\
33 & $\begin{array}{l}\text { The salary scale of the council is below what is } \\
\text { stated in the Palestinian Civil Service Law. }\end{array}$ & 2.67 & 53.43 & 5.19 & $0.000^{*}$ & 2 \\
34 & $\begin{array}{l}\text { The salary scale of the council is below the standard } \\
\text { living in the society. } \\
\text { By time, employee's enthusiasm to continue working } \\
\text { for the interest of the council is weak. }\end{array}$ & 2.63 & 52.50 & 6.29 & $0.000^{*}$ & 3 \\
\hline
\end{tabular}

*The mean is significantly different from 3

performance of the JSC-SWM. Table 12 shows means and test values for the fifth field.

According to the data in table 12, it can be concluded that there is a significant relationship between compensations and the performance of the JSC-SWM.at level of $(0.05 \%)$.

Hypothesis 6: There is a statistically significant relationship at $\mathbf{a}=0.05$ in the responses due to the differences of personal characteristics among employees.
This hypothesis can be split into the following subhypotheses:

- There is a statistically significant relationship at $a=0.05$ in the responses among employees due to experience. Table 13 shows ANOVA test of the fields and their $p$-values for Experience. It can be concluded that there are no statistically significant differences among the respondents due to the experience. 
Table 13: ANOVA test of the fields and their $p$-values for Experience

\begin{tabular}{|c|c|c|c|c|c|}
\hline \multirow[b]{2}{*}{ Field } & \multicolumn{3}{|c|}{ Means } & \multirow{2}{*}{$\begin{array}{c}\text { Test } \\
\text { Value }\end{array}$} & \multirow[b]{2}{*}{ Sig. } \\
\hline & $\begin{array}{l}\text { Less than } 10 \\
\text { years }\end{array}$ & $\begin{array}{l}10-20 \\
\text { years }\end{array}$ & $\begin{array}{l}20 \text { years } \\
\text { and more }\end{array}$ & & \\
\hline Adopting proper budgets & 5.73 & 6.35 & 7.35 & 4.008 & 0.235 \\
\hline Filling positions with local ordinances & 6.24 & 6.13 & 6.58 & 0.568 & 0.570 \\
\hline Pensions and retirement system & 7.08 & 6.78 & 7.77 & 2.095 & 0.133 \\
\hline Fines and penalties for violation of ordinances & 6.83 & 6.90 & 7.44 & 1.067 & 0.352 \\
\hline Compensations & 6.53 & 6.58 & 7.30 & 2.225 & 0.118 \\
\hline
\end{tabular}

${ }^{*}$ The mean difference is significant at 0.05 level

Table 14: ANOVA test of the fields and their p-values for Education

\begin{tabular}{|c|c|c|c|c|c|}
\hline \multirow[b]{2}{*}{ Field } & \multicolumn{3}{|c|}{ Means } & \multirow[b]{2}{*}{ Test Value } & \multirow[b]{2}{*}{ Sig. } \\
\hline & $\begin{array}{c}2 \text { year } \\
\text { diploma }\end{array}$ & $\begin{array}{c}\text { Bachelor's } \\
\text { Degree }\end{array}$ & $\begin{array}{c}\text { Master's Degree } \\
\text { and more }\end{array}$ & & \\
\hline Adopting proper budgets & 6.80 & 5.97 & 6.89 & 2.467 & 0.095 \\
\hline Filling positions with local ordinances & 5.90 & 6.31 & 6.27 & 0.227 & 0.798 \\
\hline Pensions and retirement system & 7.93 & 6.78 & 7.25 & 1.691 & 0.194 \\
\hline $\begin{array}{l}\text { Fines and penalties for violation of } \\
\text { ordinances }\end{array}$ & 7.43 & 6.75 & 7.23 & 1.393 & 0.258 \\
\hline Compensations & 6.75 & 6.71 & 7.30 & 1.589 & 0.247 \\
\hline All Independent Variables Together & 7.07 & 6.49 & 6.94 & 1.313 & 0.278 \\
\hline
\end{tabular}

${ }^{*}$ The mean difference is significant at 0.05 level

- There is a statistically significant relationship at $\mathrm{a}=\mathbf{0 . 0 5}$ in the responses among employees due to due to education. Table 14 shows ANOVA test of the fields and their $p$-values for Education. It can be concluded that there are no statistically significant differences among the respondents due to the experience.

- There is a statistically significant relationship at $\mathrm{a}=\mathbf{0 . 0 5}$ in the responses among employees due to due to position. Table 15 shows ANOVA test of the fields and their $p$-values for Position. It can be concluded that there are no statistically significant differences among the respondents due to the experience.

\section{RESULTS}

In the light of the results of this research, it can be included the following:
Without any doubt, the proper budgets of the JSCSWM has significant relation with the efficient and effective performance of the council and its services to citizens and this result matches with the studies of Bell and Warner (2013) and Bolgherini (2011).

Filling positions with local ordinances reinforces and supports the performances of the JSC-SWM and this is matching with the study of Saleh and Saad (2010) and Shorab, (2007).

The financial reinforcements are strong fortifications for efficient and the effective performance of the JSC-SWM and the absence of different types of payments and fair retirement plan influences negatively the performance. This result matches with the study of Abo-Made (2004) and Awad, (2005).

The financial punishments are strong tool on correcting the wrong practices and modifying the weak performance of the JSC-SWM. The result agrees with the study of Kolab (2004) and Abu Al-Ajeen (2010). 
Table 15: ANOVA test of the fields and their $p$-values for Position

\begin{tabular}{|c|c|c|c|c|c|c|c|}
\hline \multirow[b]{2}{*}{ Field } & \multicolumn{5}{|c|}{ Means } & \multirow{2}{*}{$\begin{array}{l}\text { Test } \\
\text { Value }\end{array}$} & \multirow[b]{2}{*}{ Sig. } \\
\hline & $\begin{array}{l}\text { Head of } \\
\text { Dept. }\end{array}$ & $\begin{array}{c}\text { Head of } \\
\text { Divisions }\end{array}$ & Engineer & Administrative Staff & $\begin{array}{c}\text { Technician } \\
\text { Staff }\end{array}$ & & \\
\hline Adopting proper budgets & 7.14 & 7.03 & 6.18 & 5.81 & 6.59 & 1.172 & 0.334 \\
\hline $\begin{array}{l}\text { Filling positions with local } \\
\text { ordinances }\end{array}$ & 5.73 & 6.42 & 6.29 & 6.03 & 6.46 & 0.352 & 0.841 \\
\hline $\begin{array}{l}\text { Pensions and retirement } \\
\text { system }\end{array}$ & 7.81 & 6.84 & 6.83 & 7.49 & 7.10 & 0.678 & 0.610 \\
\hline $\begin{array}{l}\text { Fines and penalties for } \\
\text { violation of ordinances }\end{array}$ & 7.06 & 6.87 & 7.01 & 6.95 & 7.16 & 0.074 & 0.990 \\
\hline Compensations & 7.65 & 6.56 & 6.01 & 6.45 & 7.34 & 0.069 & 0.763 \\
\hline $\begin{array}{l}\text { All Independent } \\
\text { Variables Together }\end{array}$ & 6.94 & 6.80 & 6.63 & 6.63 & 6.87 & 0.137 & 0.968 \\
\hline
\end{tabular}

*The mean difference is significant at 0.05 level

Although the absence of fair compensations that match with the current Palestinian standard of living does not motivate employees to leave their work in the JSC-SWM, employees' enthusiasm to work hard decreases by time Al-Aksh, (2007).

The JSC-SWM does not have a policy which can regulate the issues of fines and penalties for violation of ordinances that might be committed by the member municipalities and this agrees with the study of Bolgherini (2011).

The Palestinian Ministry of Local Governance doesn't explain the offered types of reinforcements or punishments to the employees of the JSC-SWM, and the employees know that the different aspects of the Palestinian Civil Service Law and Palestinian Labor Law organize regulate their work. This is in contrast with the municipalities' employees whose work is regulated only by the Palestinian Civil Service Law and this is matching the study of Awad (2005).

The JSC-SWM doesn't reinforce its employees enough whether financially or un-financially to do their own job well due to lack of funds and this is matching with the study of Shorab (2007).

Reinforcements and punishments in the JSC-SWM are not introduced according to the yearly performance appraisal report and this is matching the study of Awad (2005).

Personal characteristics of employees did not influence their answers regarding the necessity to have proper budgets, filling positions with local ordinances Pensions and retirement system, compensations, fines and penalties for violation of ordinances.

\section{Recommendations:}

In light of the aforementioned results, the following points are recommended:
- The JSC-SWM has to revise its offered reinforcement policy for its employees to keep its services up to the planned level.

- The JSC-SWM has to start imposing punishment policy in the needed cases, and develop methods and techniques of punishments for the member municipalities for not paying their financial entitlements.

- The Palestinian Ministry of Local Governance has to deal with the staff of the JSC-SWM equally and fairly and in the same way of the municipalities' staff who are subjected to the Palestinian Civil Service Law.

- The JSC-SWM should start adopting scientific tools, and with financial experts or consultants, for designing proper budgets that can promote the performance of the council.

- The JSC-SWM should offer reinforcements according to the performance appraisal reports, to maintain fairness and justice.

- The JSC-SWM should reinforce employee's attitudes against wrong practices by providing employees with suitable training courses.

- The JSC-SWM has to improve its response to employees' performance during the year, and not only at the end of the year.

\section{Suggested Further Studies}

According to author's knowledge, this is the first study to be conducted on the factors that might influence the performance of The JSC-SWM in Gaza Strip. This field of research is completely new and deserves more exploration in the Palestinian society. Therefore, the following future studies are suggested: 
- The validity and reliability of the performance appraisal system adopted by the joint service councils and the Palestinian Ministry of Local Governance.

- The validity and reliability of budget system adopted by the Palestinian Ministry of Local Governance.

- Corruption channels in the Palestinian Ministry of Joint Service Council and in the PNA institutions in general.

\section{REFERENCES}

Abo-Made K (2004). The Effectiveness of Control Methods in Public Institutions in Gaza Strip. The Islamic University in Gaza.

Abu Al-Ajeen TY (2010). The Impact of Organizational Obstacles on the Performance of Local Authorities in Gaza Strip. Gaza: The Islamis Universsity in Gaza.

Al Masri RM (2012). Functional Role Ambiguity and Its Impact on Delegation, Applied Study on the Ministry of Local Government. Gaza: Islamic University in Gaza.

Al-Aksh A (2007). The Effect of Reinforcement and Rewards System on Improving Performance of Employees in The Palestinian Ministries. The Islamic University in Gaza

Awad T (2005). Evaluation of Employees' Performance Appraisal System in The Palestinian National Authority in the Gaza strip. The Islamic University in Gaza

Bel G, Warner ME (2013). Factors Explaining Inter-municipal Cooperation in Service Delivery: A Meta-Regression Analysis. Public Management Research Association Conference. Madison, WI: University of Wisconsin-Madison.

Bolgherini S (2011). Local Government and Inter-Municipal Cooperation in Italy and Germany. Gießen: PIFO: Politische Italien-Forschung.

Bushra M (2000). Policies and Institutional Assessment of Solid Waste Management in Five Countries: Egypt. United Nations Environment Program, CEDARE, PlanBlue.

Coalition for Accountability and Integrity (AMAN). (2009). Combating Corruption in Public Institutions, Coalition for Accountability and Integrity (AMAN).

Coalition for Accountability and Integrity (AMAN). (2009). Palestinian Anti-Corruption Policies and Legislations.

Daifi DZ (2012). Development of an Institutional Framework and Organizational Structures for Water and Sanitation S ervice Providers in the West Bank - Palestine. Nablus: An-Najah National University.

Diaz LF, Savage GM, Eggerth LL (2005). Solid Waste Management. United Nations Environment Programme, Division of Technology, Industry and Economics.

EEA (2013). Managing Municipal Solid Waste - a review of achievements in 32 European Country. European Environment Agency. Copenhagen: Luxembourg: Publication Office of the European Union.

El-Medhoun N (2015). The Extent of Applicability of Municipal Cooperative Service Provider Solid Waste Management Council in North Gaza Governorate, Unpublished thesis, The Islamic University of Gaza, 2015.

Hoornweg D, Bhada-Tata P (2012). WHAT A WASTE A Global Review of Solid Waste Management. The World Bank, Urban Development and Local Government Unit. Washington: The World Bank.

Jabr MH (2004). A Municipal Management and Decentralization Policy. Nablus: An-Najah National University.

Kolab S (2004). The Reality of Internal Monitoring in The Palestinian Public Sector. The Islamic University in Gaza

Li K (2007). Study of Influence Factors in Municipal Solid Waste Management Decision-making. Master of Science Thesis, Royal Institute of Technology, Industrial Ecology.

MDLF (2009). Gaza Municipal Sector Damage Assessment. Municipal Developemnt and Lending Fund (MDLF).
MDLF (2014). Rapid Assessment of Gaza Municipal Sector Damage. Gaza: MDLF.

Ministry of Local Governance. (2009). MoLG. Retrieved January 20, 2014, from http://www.molg.pna.ps http://www.molg.pna.ps/Join council aboutus.aspx

Municipal Research and Services Center of Washington (1999). Local Government Policy-Making Process. Seattle: Municipal Research and Services Center of Washington.

Palestinian Legislative Council (1998). The Civil Law, Palestinian Legislative Council.

PCBS (2012). Palestinian Central Bureau of Statistics. Retrieved May 20, 2015, from Palestinian Central Bureau of Statistics Web site: http://www.pcbs.gov.ps/Portals/ Rainbow/Documents/GS\%20E2A\%2 02013.htm

Safi W, Luecke M (2007). Higher Efficiency and Effectiveness in Public Services through Regional Approaches - Joint Solid Waste Management Councils. Eleventh International Waste Management and Landfill Symposium. Sardinia: CISA, Environmental Sanitary Engineering Centre, Italy.

Saleh AA, Saad AM (2010). Absence of Some Administrative Practices and Its Impact on Level of Services. Al-Gharee for Econ. Admin. Sci. 234-251.

Shorab, B. (2007). Evaluating The Effect Of Incentives System on Employees Performance Level in The Large Municipalities of Gaza Strip. The Islamic University in Gaza

Soufan BR (2012). Solid Waste Management in the West Bank: Institutional, Legal, Financial Assessment and Framework Development. Nablus: An-Najah National University.

The World Bank (2012). WHAT A WASTE, A Global Review of Solid Waste Management. The World Bank, Urban Development and Local Government Unit. Washington: The World Bank.

UNEP (2003). Desk Study on the Environment in the Occupied Palestinian Territories. Geneva: United Nations Environment Programme. 